\title{
Master's level education in biomedical optics: four-year experience at the University of Latvia
}

Janis Spigulis

Janis Spigulis, "Master's level education in biomedical optics: four-year experience at the University of Latvia," Proc. SPIE 3831, Sixth International Conference on Education and Training in Optics and Photonics, (16 June 2000); doi: 10.1117/12.388727

EPIE Event: Education and Training in Optics and Photonics (ETOP'99), 1999, Cancun, Mexico 


\title{
Master's level education in Biomedical Optics: four-year experience at University of Latvia
}

\author{
Janis Spigulis \\ University of Latvia, Department of Physics, Raina Blvd. 19, Riga, LV-1586, Latvia
}

\begin{abstract}
Pilot program for Master's studies on Biomedical Optics has been developed and launched at University of Latvia in 1995. The Curriculum contains several basic subjects like Fundamentals of Biomedical Optics, Medical Lightguides, Anatomy and Physiology, Lasers and Non-coherent Light Sources, Optical Instrumentation for Healthcare, Optical Methods for Patient Treatment, Basic Physics, etc. Special English Terminology and Laboratory-Clinical Praxis are also involved, and the Master Theses is the final step for the degree award. Following our four-year teaching experience, some observations, conclusions and eventual future activities are discussed below.
\end{abstract}

Keywords: biomedical optics education, Master's study programs.

\section{INTRODUCTION}

Physics post-graduate program at University of Latvia offers a wide variety of study sub-programs, and Biomedical Optics as a very rapidly developing inter-disciplinary research and application area was also included there four years ago. Detailed description of its basic course - Fundamentals of Biomedical Optics - was presented at the previous ETOP conference '. This paper gives a deeper insight in the other courses and in the whole Curriculum design. Recently some internationalization of this program was initiated in frame of a European TEMPUS project ${ }^{2}$, and new activities like development of a specialized Biomedical Optics library and facilities for student's laboratory works with bio-optical equipment were started. Several aspects of the teaching experience and technology will be critically analyzed below.

\section{THE CURRICULUM}

The Curriculum for the two-year/four-semester Biomedical Optics Master's studies presently includes following subjects (with the corresponding credits):

No. SEMESTER

1.1

2. 1

3. 1

4. 1

5. 1

6. 2

7. 2

8. 2

9.2

10. 2

11. 3

12. 3

\section{SUBJECT}

Fundamentals of Biomedical Optics - I (Tissue Optics, Optical Sensing for Diagnostics and Monitoring) Basic Physics Optical Instrumentation for Healthcare Computer Skills

Fundamentals of Opto-electronics

Anatomy and Physiology

Lasers and Non-coherent Light Sources

Medical Lightguides

Special English Terminology

Methods of Experimental Spectroscopy

Fundamentals of Biomedical Optics - II

(Laser-Tissue Interaction, Laser Medicine)

Optical Methods for Patient Treatment

\section{PART CREDITS EXAM/PASS}

$\begin{array}{lll}\text { A } & 4 & \text { P } \\ \text { A } & 4 & \text { E } \\ \text { A } & 4 & \text { E } \\ \text { B } & 3 & \text { P } \\ \text { B } & 3 & \text { P } \\ \text { A } & 4 & \text { E } \\ \text { A } & 4 & \text { E } \\ \text { A } & 4 & \text { P } \\ \text { B } & 3 & \text { P } \\ \text { B } & 3 & \text { P } \\ \text { A } & 4 & \text { E } \\ & & \\ \text { A } & 4 & \text { E }\end{array}$

(to be continued on the next page) 
(continued)

No. SEMESTER

13. 3 Laboratory - Clinical Praxis

14. 3 Special English

15. 3 Optical Sensors and Analytical Devices

16. 4 Techniques of Laser Medicine

17. 4 Master Thesis
PART CREDITS EXAM/PASS

$\begin{array}{lll}\text { A } & 3 & \text { P } \\ \text { B } & 3 & \text { P } \\ \text { B } & 3 & \text { P } \\ \text { A } & 4 & \text { P } \\ \text { A } & 32 & \text { D }\end{array}$

\begin{tabular}{ll}
\hline Abbreviations: & \\
\hline A - compulsory subjects, & $\mathrm{P}$ - pass without mark, \\
B - free choice subjects. & E - exam with mark, \\
& D - public defense of the Thesis.
\end{tabular}

To receive the Master's degree, students must collect at least 80 credits - to pass 10 compulsory (A) and 3 free choice (B) subjects out of 6 , and to defend their Master Thesis. To start the Master studies, the Bachelor degree in physics, engineering or life sciences is required. Brief abstracts of the basic compulsory courses are given below.

Fundamentals of Biomedical Optics ${ }^{1}$ as the largest course $(8$ credits) is divided into two parts. The first part includes Tissue Optics (propagation of optical radiation in tissues, skin optics, blood optics, eye optics and optics of the hard tissues) and Optical Sensing for Diagnostics and Monitoring (photoplethysmography, pulse oximetry, laser-Doppler blood flowmetry, NIR monitoring of cerebral oxygenation, optical sensors of physical and biochemical parameters, spectrometric sensors and fluorosensors). The second part covers laser-tissue interactions and laser treatment (medical lasers, laser safety, laser biostimulation, laser photodynamic therapy - PDT, laser applications in cosmetology, surgery, dentistry and other medical specialties).

Optical Instrumentation for Healthcare is a course giving overview on the basic principles and design solutions of the optical equipment used in clinical environment - microscopes, polarimeters, spectrometers, neftelometers, etc.

Anatomy and Physiology course is addressed mainly to the students with physics and engineering background. Its anatomy part regards the composition of human body, structure of brain, heart, kidneys and other organs, as well as the neural, respiratory, reproductive and other essential living systems. The physiology part includes homeostasis, blood supply, muscle dynamics, cellular structures and physiological functions of the basic human organs.

Lasers and Non-coherent Light Sources is a course explaining basic physical principles of non-coherent and coherent light emission. It regards specific features of various laser types (gas, solid state, semi-conductor, excimer, etc.) and their applications in non-linear optics, spectroscopy, environmental studies and medicine. Non-coherent sources like halogen lamps and discharge tubes are regarded, as well.

Medical Lightguides is a course concerning basic of fiber optics and applications of fiber lightguides in various medical devices - fibroendoscopes, "cold light" and non-shadow illuminators, medical laser delivery systems, phototherapy units, bio-optical sensors, etc.

Optical Methods for Patient Treatment is a clinically oriented course on thermal and non-thermal laser interactions with living tissues. Laser therapy (including laser acupuncture and combined magneto-optical procedures) and laser surgery (including eye surgery) are regarded in details in frame of this course.

The other courses included in the Curriculum are of a major importance, as well; however, their content will dot be discussed in this paper. 


\section{PRACTICAL ASPECTS}

A team of eight lecturers teaches the Biomedical Optics sub-program; five of them are the professor-level teachers. Typically about ten students formed the $1^{\text {st }}$ semester group in years $1995-1998$. Regarding their backgrounds, the physics, engineering and life science backgrounds were distributed nearly equally. Two distinct age groups of the students were identified - one of just graduated ( $23 \ldots 25$ years) students, the other of more experienced ( $30 \ldots 40$ years) persons. Female to male relation in groups was roughly $2: 1$.

One of the biggest teaching problems was and still is the lack of suitable textbooks in the profile topics. The field is emerging very dynamically, and regular studies of the periodicals (e. g. the journals "Biomedical Optics" and "Biophotonics") are always necessary. However, there is also a lot of proved and established knowledge which is mainly available in review articles, and only few specialized books can be recommended for students. This year we started to create the Biomedical Optics library; now it consists of about 100 units - books (or copies of their chapters), conference proceedings and periodicals. Several collected books are cited here ${ }^{3-20}$, and selected chapters at some of them ${ }^{3-5,10-15}$ we find quite suitable for the students as the basic literature sources.

Acquisition of practical skills is a very important aspect of the teaching process. Laboratory-Clinical Praxis is included in the part A of the study plan at the $3^{\text {rd }}$ semester. During this praxis students spend certain time (at least 6 full days) in real laboratory or clinical environment dealing independently with some particular problem. If this work is successful, it is usually extended at the Master's project. A further step to increase the role of practical activities is development of the student's laboratory on Biomedical Optics. Several student practicals concerning optical properties of tissues (laser light scattering from tissue samples and phantoms; light penetration, transmission and absorption in tissues; laser-excited tissue fluorescence) and the non-invasive optical diagnostics (photoplethysmography, pulse oximetry, laser-Doppler blood flowmetry) are going to be worked-out.

The development of the specialized library and student's laboratory on Biomedical Optics was possible thanks to financial support from the European structures in frame of the TEMPUS project ${ }^{2}$ incorporating five Baltic universities and two from the EU countries (Linkoping University, Sweden, and King's College London, UK). University of Latvia is recognized as the regional center of excellence on Biomedical Optics teaching in frame of this project. International links are developed also with other European universities, e. g. Lund University (Sweden), University College London (UK), University of Patras (Greece). Development of specialized regional or international centers seems to be a future trend of providing Master's education on narrow inter-disciplinary subjects, and University of Latvia eventually might be such a center in the field of Biomedical Optics education in future.

Several problems in the Biomedical Optics teaching area have been identified and extensively discussed:

- substantial differences in student's background knowledge levels, especially on physics; medical graduates sometime have difficulties to follow the lectures on special subjects, even after passing the Basic Physics course at the $1^{\text {st }}$ semester;

- the Curriculum does not cover all aspects of the area; in particular, Medical Imaging and probably some more subjects ought to be added in future, thus changing the existing balance of subjects;

- the Master's study program is fairly time-consuming ( 2 years), and many students cannot afford to spend all their time for studies; therefore the mean successful output rate for this sub-program has been only about $30 \%$;

- the research activities on the subject should be developed more actively, and additional research funding is needed;

- the program has relatively weak support by the local clinical and medical institutions;

- the program offers only academic degree without any professional certificate (which sometimes can be of value, e. g. for the young clinicians);

- the social need for this kind of specialists is relatively low, but it will definitely grow in future.

\section{CONCLUSIONS}

1. Master's education on Biomedical Optics at University of Latvia has proved its viability.

2. The Curriculum ( 80 credits) covers the basic topics of the field; however, regular updating of the Curriculun and the course Syllabi would be necessary. 
3. To provide further improvements of the teaching quality, the specialized Biomedical Optics library and student's laboratory are under development.

4. Several practical problems associated with Master's teaching in Biomedical Optics have been identified and discussed.

5. International collaboration in the Biomedical Optics education is rapidly developing; any suggestions, proposals and comments on this would be highly appreciated.

\section{REFERENCES}

1. J. Spigulis, "MSc course programme on Biomedical Optics", SPIE Proc. Vol. 3190, 1997, pp. 342-345.

2. Y. Dekhtyar, et al., "Joint Baltic Biomedical Engineering and Physics courses", Med. Biol. Eng, Comput., 37, Suppl. 1, 1999, pp. 144-145.

3. A. J. Welsh, M. van Germet, Optical Thermal Response of Laser-Irradiated Tissue, Plenum Press, NY, 1995.

4. J. D. Regan, J. A. Parrish, The Science of Photomedicine, Plenum Press, NY, 1982.

5. S. L. Jacques, Tissue Optics, SPIE Short Course Notes SC34, Bellingham, 1996.

6. M. H. Niemz, Laser-Tissue Interactions: Fundamentals and Applications, Springer, Berlin, 1996.

7. C. A. Puliafito (ed.), Laser Surgery and Medicine: Principles and Practice, Wiley-Liss, NY, 1996.

8. H. W. Lim, N. A. Soter, Clinical Photomedicine, Marcel Dekker, NY, 1993.

9. L. I. Grossweiner, The Science of Phototherpy, CRC Press, Boca Raton, 1994.

10. A. P. Shepard, P. A. Oberg, Laser Doppler Blood Flowmetry, Kluwer Publ., Boston, 1990.

11. A. Katzir, Lasers and Optical Fibers in Medicine, Academic Press, NY, 1993.

12. J. S. Gravenstein, Gas Monitoring and Pulse Oximetry, Butterworth-Henemann, Boston, 1990.

13. J. P. Payne and J. W. Severinghaus, Pulse Oximetry, Springer, Berlin, 1986.

14. O. Svelto, Principles of Lasers, Plenum Press, NY, 1998.

15. D. H. Sliney (ed.), Laser Safety, SPIE Vol. MS117, Bellingham, 1995.

16. D. Sliney, Safety with Lasers and Other Optical Sources, Plenum Press, NY, 1982.

17. G. J. Mueller (ed.), Laser-Induced Interstitial Thermotherapy, SPIE Vol. PM25, Bellingham, 1995.

18. C. J. Gomer (ed.), Future Directions and Applications in Photodynamic Therapy, SPIE Vol. IS06, Bellingham, 1990.

19. G. J. Mueller et al. (ed.), Medical Optical Tomography: Functional Imaging and Monitoring, SPIE Vol. IS11, Bellingham, 1993.

20. U. Dugnali et al., Optical Imaging of the Brain Functions and Metabolism, Plenum Press, NY, 1993. 